\title{
THE ROLE OF INFORMATION IN FINANCIAL DECISION MAKING PROCESS: A THEORETICAL VIEW
}

IZET ZEQIRI, Ph.D.

https://doi.org/10.35945/gb.2017.03.002

Full Professor, South East European University,

Associate Member of the Macedonian Academy of Sciences and Arts, Macedonia

FITIM DEARI, Ph.D.

Assistant Professor, South East European University, Macedonia

SADRI ALIJI, Ph.D.

Assistant Professor, South East European University, Macedonia

KEYWORDS: INFORMATION, DECISION, SYSTEM

\section{INTRODUCTION AND LITERATURE REVIEW}

Firms in everyday life face different business decisions, which are linked with internal and external factors. Such decisions may include: what/where/when/how to produce a product and (or) service, what is the production cost, who is client, what price to set, do the product/service differs from what competitors do, future business climate will be better or worse, etc. No doubt that there are many other questions/dilemmas appeared by decision makers and there is no unique formula for solving them. Each business decision case should be treated in context of the proposed problem. Even to, a business decision case and therefore financial decisions can be view from different perspectives by different decision makers.

Indeed, decision makers use information in function to decrease the business uncertainty. For example, accounting information users use financial statement analysis in order to make better sound decisions. "Financial statement analysis reduces our reliance on hunches, guesses, and intuition, and in turn it diminishes our uncertainty in decision making." (Bernstein and Wild, 1998:3)

Creation and building of the information database for making decisions in a firm should start with the concept, so information related with firm's works have to be generated and flow based on concretely demands of the firm's policy. In this context, also information for financial policy needs "relied" in this base. Thus, based on this concept financial policy is the fundament, a source of any information systems for rational leading and advancing finances of a firm. In further development of this concept, is obvious that collecting different information for financial processes serves as the source for control and analysis of the firm's financial policy. Through analysis process is performed processing, selection of evidence data, transformation of them into working information and division of them according purposes. When information come in appropriate point, they become valuable, serve for dynamic controlling and are instrument of working decisions for financial processes.

In current conditions, information creates prior conditions for existing and development of modern firms. Their managers, based on problems study, respectively providing of information from information system, make decisions and care for their implementation (Zeqiri, 1999:73).

Based on above discussion, information-organizing phases can be listed as:

- The phase of ensuring adequate information sources which has to do with events in financial processes;

- The phase of systematic analysis of information with purpose of preparing, processing and selection of information which are in accordance with the work;

- The phase of launching processed information from a destination to users; and

- The phase of utilization obtained information according responsibilities and function from the firm's bodies.

All these stages move or intertwined according to the specific concrete requirements of financial management in order to progress to the firm's financial processes. This means that, at the beginning and during construction the working information system for financial processes definitely is, under this concept, to take account for the purposes of the firm's financial policy.

In modern terms, the financial management involves solving three major decisions in the firm, i.e. (1) decisions regarding investments, (2) decisions regarding financing, and (3) decisions regarding the distribution of results. These decisions jointly determine the value of the firm. When you thought that the purpose of the firm is to maximize this value, the firm should be striving for an optimal combination of these three key decisions related to each other, which solved simultaneously (Horne, 1993:10).

For an optimal combination of these decisions it is necessary to establish a sound information base that would precede the process of financial decision making. For making and implementation of major decisions in financial management is required a large number of internal and external information. The quality of crucial decisions in financial management primarily depends on the quality of the available information. 


\section{DISCUSSION - ACCOUNTING INFORMATION,} DATABASE AND FINANCIAL DECISION MAKING

In any firm in accordance with the division of labor there are different business functions. Each function has its own policy. Policy of business functions include policy goals and principles, which adhered to the achievement of goals. The goals of business functions must be in harmony with the final goal of the firm and they must also be understood as subgoals of the firm's policy goals.

Financial policy as a policy of the financial function has goals and principles as a source of data on the basis of which works towards realizing the goals. The aim of the financial policy is to increase the firm's financial strength. But, financial power means (Kralj, 1990):

- Sustainable solvency ability,

- Sustainable financing ability,

- Sustainable investment ability,

- Ability to increase the wealth of owners, and

- Ability to meet the financial interests of the participants in the firm.

Financial policy requires that the need for financial decisions have a huge amount of information, which will not only be to support the decision, but also support for the possible consequences of the financial decision. The information system which is not well regulated, only with partial information, leads to the creation of routine financial decisions that are not always rational.

Today financial theory and practice in the course of time have developed various methods for evaluating and ranking of investment projects on the basis of prospective, desired profitability (Krasulja, 1998:305). All these modern methods in fact give us the desired information to accurately assess the economic costs and forecast, accurate calculation of revenues that will be realized by the firm's application of any concrete plan investments.

Within the firm's business system, accounting information system occupies an important place, which is closely linked to the accounting data. In fact, the accounting information represents a sound information base necessary for the conducting of business processes within the firm. Accounting information arising from the accounting information system in most cases, presents the initial data, so it is often necessary for them to be processed in order to be meaningful in the overall process of decision making.

Accounting service due to factors that influenced it, in many countries as in Macedonia too experienced and set new tasks related to meeting the needs, said conditionally modern needs of information users regarding decision making at various levels and by various interest groups. In current practice, financial reports have been designed to provide information which has been in function of protection and growth of social wealth, for the purpose of taxation and the overall economy leadership. The development of a market economy and forms of ownership in Macedonia, and capital structure, in the first place put the interests of the owners of capital and the obligation of management to fulfill these interests (Rusevski, 1999:27). This situation required retraining necessary information from financial reports in order to satisfy the management needs of each individual entity.

Within a firm-entity occur different activities related with production, selling, buying, etc. At commercial-business entities these are known as business activities. These business activities are recognized as transactions, commonly as financial transactions, via accounting documents. It is the job of bookkeeper to record these transactions. Till this point records present just accounting data which nowadays are processed much easier comparing with the past, thanks implementation of computer-electronic software accounting-financial packages. But, accounting as an information system doesn't ends up here. Collected accounting data (inputs) will be processed furthermore (the process) and will be transformed to outputs (financial statements). An illustrated view is given as below (Figure 1):

Figure 1 presents clearly that the bookkeeping is just a part of the overall accounting process. Thus, the accounting process provides information via outputs, mainly in form of financial statements such as: balance sheet, income statement, statement of cash flows, statement of owner's equity,

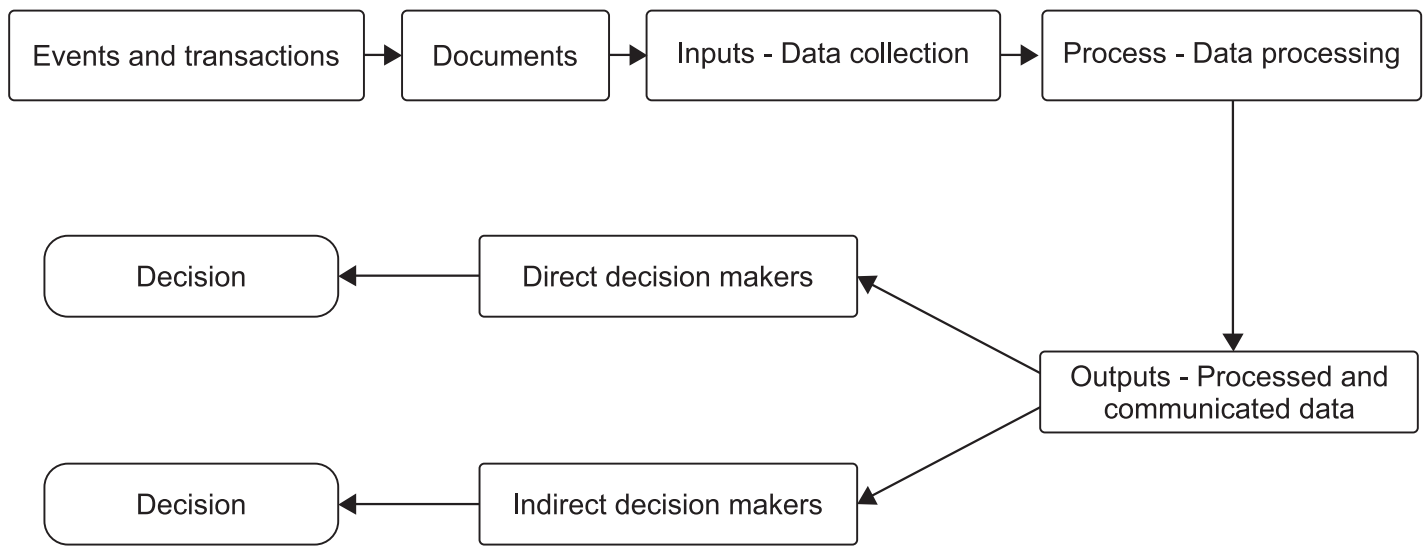

Figure 1: Accounting as an information system. Source: Based, adopted and reprocessed from Dhamo (2003:30). 
and other financial reports. These reports are addressed to different interest groups, which in accounting and financial theory-practice commonly are divided as internal or external users. Needles and Powers (2005:4) divide accounting information users-decision makers into three groups: (1) management; (2) those with direct financial interest such as investors and creditors; (3) those with indirect financial interest such as tax authorities, regulatory agencies, labor unions, financial advisers, customers, and economic planners. All these groups are interested for the firm and view it from different prism of interest, including here financial decisions. They read information from financial statement in order to improve the quality of decision making.

The importance of information is that they show something new on the basis of which current decisions are taken and firm's activities are directed towards achieving business goals. Thus, accounting information is derived from the analytical processing of accounting data. They preceded the collection process, adjustment and data processing based on quantitative analysis and interpretation in the form of reports.

The primary task of the firm's accounting information system is to provide adequate information for making optimal decisions for the governance and leading of its activities. Only qualitative information can be efficiently accomplished business and financial policy. The quality of current decisions in the firm depends on the quality of accounting information which should be relevant, accurate, complete, clear and in time. Accounting information is used at all levels of government. At the strategic level the processed information (as usually is synthetic and aggregate), is directed towards the future and include a longer time. Tactical level uses information, which includes recent past and future. For operational decision making process the information (detailed and analytic) is used which includes the current state and has informative nature.

\section{CONCLUSIONS}

In current conditions, information creates prior conditions for existing and development of modern firms. Complexity related with business decisions is increasing day by day due to many factors, inside and outside the firm. In these circumstances it is more than necessary to have a system that will provide information in function of users' needs and requirements. Information related with the firm's activities has to be generated and flow based on concretely demands of its policy. Generation and furthermore using information follow a process of transforming data into information, processing, selection of data, transforming them into working information and dividing them according purposes. Furthermore, the information becomes valuable when it goes to user(s), serves for dynamic controlling and is instrument of working decisions.

\section{REFERENCES:}

1. Bernstein A., Leopold, J. Wild, John, Financial Statements Analysis: Theory, Application, and Interpretation, McGraw-Hill, Boston, 1998.

2. Dhamo, Sotiraq M., Kontabiliteti Financiar, Tiranë, 2003.

3. Horne, James C. Van, Finansisko upravlanje i politika (Finanansiski menadzment), Stanford University, MATE-Zagreb, 1993.

4. Kralj, Janko, Finansisko upravlanje i finansisko poslovanje u uslovima trzisne privrede, Knjigovodstvo, Br. 8-9, Zagreb, 1990.

5. Krasulja, Dragan, Poslovne financije, Ekonomski Fakultet, Beograd, 1998.

6. Needles, E. Belverd, Powers, Marian, Principles of Financial Accounting, Houghton Mifflin Company, Boston, 2005.

7. Rusevski, Trajko, Smetkovodstveno-Finansiska Revija, 1999.

8. Zeqiri, Izet, Roli i informacionit për Financat e Ndërmarrjes (Tranzicioni Ekonomik në Maqedoni), Revista ekonomike EKONOMIA dhe TRANZICIONI, Nr. 2, Prill-Qershor, Tiranë, 1999. 


\section{THE ROLE OF INFORMATION IN FINANCIAL DECISION MAKING PROCESS: A THEORETICAL VIEW}

IZET ZEQIRI, Ph.D.

https://doi.org/10.35945/gb.2017.03.002

Full Professor, South East European University;

Associate Member of the Macedonian Academy of Sciences and Arts, Macedonia

FITIM DEARI, Ph.D.

Assistant Professor, South East European University, Macedonia

SADRI ALIJI, Ph.D.

Assistant Professor, South East European University, Macedonia

KEYWORDS: INFORMATION, DECISION, SYSTEM

\section{SUMMARY}

The role and place of information in financial decision making process is undisputed. The financial decision that doesn't rely on information would be inaccurate and costly. Information serves and helps in the decision making process both information users, internal and external. Thus, nowadays firms pay enough attention to the construction of appropriate information systems. Such information systems should be able to provide information in time, valuable, and with many rest qualities which are required by user's needs. In the firm context, different levels of government have different needs. Whereas, the strategic level requires information that is linked with future and a longer time, the tactical level requires such information which includes recent past and future. Or, the operational level requires such information which includes the current state and has informative character. 